\title{
Clinical outcome versus post-mortem finding in cardiac surgery
}

\author{
Petr Němec, Vilém Bruk, Roman Hájek, Patrik Flodr* \\ Department of Cardiac Surgery, University Hospital, *Department of Pathology, Faculty of Medicine, \\ Palacky University, Olomouc, Czech Republic
}

\begin{abstract}
Němec P, Bruk V, Hájek R, Flodr P* (Department of Cardiac Surgery, University Hospital, *Department of Pathology, Faculty of Medicine, Palacky University, Olomouc, Czech Republic). Clinical outcome versus post-mortem finding in cardiac surgery. Cor Vasa 2006;48(3):85-88.
\end{abstract}

Introduction: The clinical diagnosis of death may be inaccurate after cardiac surgery. Autopsy is an important source of knowledge and an integral part of medical education. The only true results can be obtained by comparing the two procedures.

Methods: Data of all in-hospital deaths after cardiac surgery, occurring in a single institution between February 2002 and December 2004, were collected prospectively. Clinical diagnoses were compared with the autopsy findings.

Results: Between February 2002 and December 2004, a total of 2,613 patients were operated on. During this period, 69 deaths occurred. Autopsy was performed in 63 patients (91.3\%). The mean age of patients at death was $72.0 \pm 8.2$ years, $62 \%$ were male, $44.9 \%$ had diabetes, $63.8 \%$ had a history of myocardial infarction. Mean ejection fraction was $38.4 \pm 13.9 \%$ and mean functional class was $3.3 \pm 0.9$. The most common procedure was coronary artery bypass grafting alone in $47.8 \%$ patients, and together with other procedures in $36.2 \%$. Valve surgery was performed in $5.8 \%$ and other procedures in $10.1 \%$. The mean time to death was $12.3 \pm 16.5$ days (range 0-65 days). The most frequent cause of death was heart failure (in 47.6\%). Multiorgan failure was the cause of death in 41.3\%. Post-mortem examination revealed another or unsuspected cause of death in 8 patients (12.7\%). Three out of 8 patients died due to gastrointestinal disease. Additional findings not revealed during life were disclosed in another 6 patients, in whom the clinical and autopsy causes of death were in agreement.

Conclusions: Autopsy may identify an undiagnosed cause of death in a considerable proportion of patients following cardiac surgery. Moreover, some additional or overlooked findings may contribute to the final picture of clinical failure. Post-mortem information remains the gold standard and is a most important tool for improving clinical practice.

Key words: Cardiac surgery - Autopsy - Cause of death

Němec P, Bruk V, Hájek R, Flodr P* (Kardiochirurgická klinika Fakultní nemocnice Olomouc, *Ústav patologie Lékařské fakulty Univerzity Palackého, Olomouc, Česká republika). Porovnání klinických a pitevních nálezů v kardiochirurgii. Cor Vasa 2006;48(3):85-88.

Úvod: Klinická diagnóza při úmrtí pacienta nemusí vždy odpovídat skutečnému morfologickému nálezu. Proto teprve porovnání klinického stavu s nálezem při pitvě dá skutečnou odpověd' při hledání přičiny úmrtí.

Metodika: Formou prospektivní studie byly sledovány př́činy úmrtí u všech pacientů zemřelých po srdeční operaci v období od února 2002 do prosince 2004. Klinické diagnózy byly porovnány s pitevními nálezy.

Výsledky: Mezi únorem 2002 a prosincem 2004 bylo operováno celkem 2613 nemocných, 69 z nich zemřelo během hospitalizace na mateřském oddělení. U 63 nemocných byla provedena patologickoanatomická pitva (91,3\%). Průměrný věk nemocných byl 72,0 $\pm 8,2$ roků, $62 \%$ tvořili muži, 44,9 \% mělo diabetes mellitus a 63,8 \% prodělalo infarkt myokardu. Průměrná předoperační ejekční frakce byla $38,4 \pm 13,9 \%$ a průměrná funkční třída podle NYHA $3,3 \pm 0,9$. Nejčastějším operačním výkonem byla prostá revaskularizace myokardu u 47,8 \% nebo spojená s dalším výkonem u 36,2\%. Výkon na chlopni byl proveden u 5,8 \% a jiné operace u 10,1\%. Pacienti zemřeli v průměru $12,3 \pm 16,5$ dnů po operaci (rozmezí 0-65 dnů). Nejčastější příčinou úmrtí bylo srdeční selhání u 47,6 \%. Multiorgánové selhání se vyskytlo u 41,3 \%. Př́i pitvě byla zjištěna odlišná příčina úmrtí u 8 nemocných (12,7\%). Tři z nich zemřeli na gastrointestinální komplikace. U dalších 6 nemocných, u kterých klinická i patologická prríčina úmrtí byla v souhlase, byla odhalena další patologie, která za života nebyla známa.

Závěr: Při pitvě může být u části pacientů po srdečních operacích vyjasněna jiná přičina úmrtí než ta, jež odpovídá klinickému obrazu. Navíc mohou být zjištěny další patologie, které přispějí k ucelenému obrazu o skutečném stavu pacienta. Proto se domníváme, že i v dnešní době pitva stále patří k prostředkưm, které mohou podat informace vedoucí v konečném důsledku ke zlepšení péče o nemocné.

Klíčová slova: Srdeční chirurgie - Patologickoanatomická pitva - Příčiny úmrtí

Address: doc. MUDr. Němec Petr, CSc., Department of Cardiac Surgery, University Hospital Olomouc, I. P. Pavlova 6, 77520 Olomouc, Czech Republic, e-mail: petr.nemec@fnol.cz 
INTRODUCTION

Significant advances in diagnostic techniques, surgical skills, myocardial protection and postoperative care decrease the morbidity and mortality rates after cardiac operation. However, death continues to be a significant problem. For years, autopsy has been the established standard for determining the cause of death. However, autopsy rates have recently fallen for several reasons. Some of these could be defined as fear of litigation if unexpected findings are revealed, cost of the procedure, and the misleading concept that current diagnostic procedures and techniques are so accurate that autopsies are unnecessary. ${ }^{(1)}$ This trend, however, could threaten important feedback in surgical care. Since surgeons operate on older and sicker patients with multiple concomitant diseases, exact definition of the cause of failure remains to be an important point. Such information can lead to desirable improvement in medical care.

The aim of our prospective study was to compare the clinical versus autopsy causes of death in patients after cardiac surgery.

\section{METHODS}

Data of all in-hospital deaths after cardiac surgery between February 2002 and December 2004 in a single institution were collected on prospectively. During this period, 69 deaths occurred. Autopsy was performed in 63 patients (91.3\%). Autopsy was not performed in 6 patients due to the wish of their relatives.

Autopsy was performed according to the accepted recommendations. ${ }^{(2)}$ Close attention was then paid to the operative field to evaluate whether there were any complications directly attributable to the surgical procedure. Evidence of the disease requiring surgery was sought (coronary arteriosclerosis and myocardial fibrosis in coronary artery disease, ventricular hypertrophy/dilatation in valvular disease, etc). In the absence of any other apparent abnormality, it was assumed the cause of death was due to the disease requiring surgery. Histological examination was performed in all patients with standard sampling of all relevant organs. The post-mortem and clinical causes of death were then compared.

\section{RESULTS}

During the above period, 2,613 patients were operated on. Sixty-nine patients died, resulting in overall in-hospital mortality of $2.7 \%$. The mean age of patients at death was $72.0 \pm 8.2$ years, $62 \%$ were male, $44.9 \%$ had diabetes, $63.8 \%$ had a history of myocardial infarction. Mean ejection fraction was 38.4 $\pm 13.9 \%$ and mean functional class was $3.3 \pm 0.9$. Eighty-four percent of patients were in class III or IV (Table I). The most common operation was coronary artery bypass grafting (CABG) alone in $47.8 \%$ patients and, together with other procedures, in $36.2 \%$. Valve surgery was performed in $5.8 \%$ and other procedures in $10.1 \%$ (Table II). The mean time to death was 12.3 \pm 16.5 days (range 0-65 days). Autopsy confirmed the disease for which the operation was being performed was indeed the underlying disease in all cases. The
Table I

Clinical characteristics of the patients

\begin{tabular}{ll}
\hline \hline Age (years) & $72.0 \pm 8.2$ \\
Male/Female (\%) & $62 / 38$ \\
EF (\%) & $38.4 \pm 13.9$ \\
DM (\%) & 44.9 \\
MI (\%) & 63.8 \\
Functional class (\%) & \\
I & 7.3 \\
II & 8.7 \\
III & 34.7 \\
IV & 49.3 \\
Hemodynamic instability (\%) & 27.5 \\
\hline \hline
\end{tabular}

$\mathrm{EF}$ - ejection fraction, DM - diabetes mellitus, MI - myocardial infarction

Table II

Procedures performed in 69 patients

\begin{tabular}{lc}
\hline \hline Procedure & Number \\
CABG & 33 \\
CABG + MV repair/replacement & 8 \\
CABG + AVR & 4 \\
CABG + VSD closure & 6 \\
CABG + CEA & 4 \\
CABG + other & 3 \\
MV replacement & 1 \\
DV repair/replacement & 3 \\
AAA repair & 3 \\
Repair of RV traumatic tear & 3 \\
Repair of AA pseudoaneurysm & 1 \\
\hline \hline
\end{tabular}

CABG - coronary artery bypass grafting, MV - mitral valve, AVR - aortic valve replacement, VSD - ventricular septal defect, CEA - carotid endarterectomy, DV - double valve, AAA - acute aortic dissection, RV - right ventricle, AA ascending aorta

Table III

Clinical cause of death

\begin{tabular}{lrr}
\hline \hline Cause & \multicolumn{2}{l}{ Number } \\
Heart failure & 30 & \\
MI & \multicolumn{2}{c}{10} \\
Malignant dysrhythmias & 5 \\
MOF & 26 & 12 \\
Unknown & & 8 \\
Sepsis & & 4 \\
CVA & & 1 \\
MI & & 1 \\
Technical failure & 4 & \\
Sepsis & 4 & \\
Bleeding & 3 & \\
ARDS & 1 & \\
Pulmonary embolus & 1 & \\
Brain death & &
\end{tabular}

MI - myocardial infarction, MOF - multiorgan failure, CVA cerebrovascular accident, ARDS - adult respiratory distress syndrome

clinical causes of death are shown in Table III. The most frequent cause of death was heart failure (in $47.6 \%$ ). No other apparent abnormality related to the operation was found in 15 cases of this group. Ten patients had myocardial infarction and 5 had malignant dysrhythmias. Multiorgan failure (MOF) was the cause of death in $41.3 \%$. Autopsy did not reveal the initial cause of MOF in 12 patients. The most 
Table IV

Unsuspected causes of death and additional findings

\begin{tabular}{llc}
\hline $\begin{array}{l}\text { Clinical cause } \\
\text { of death }\end{array}$ & Pathological cause of death & Number \\
MOF & Ulcer perforation, peritonitis & 1 \\
& Bleeding ulcer, ileal necrosis & 1 \\
Heart failure & Lymphoma & 1 \\
& LV rupture & 1 \\
& Tamponade & 1 \\
Sepsis & MI & 1 \\
& Ulcer perforation, peritonitis & 1 \\
\hline \hline
\end{tabular}

MOF - multiorgan failure, LV - left ventricle, MI - myocardial infarction

Table V

Additional findings

\begin{tabular}{lc}
\hline \hline Additional finding & Number \\
Encephalomalacia & 3 \\
Small bowel infarction & 2 \\
Celiac artery thrombosis + spleen infarction & 1 \\
\hline
\end{tabular}

frequently detected causes of MOF were sepsis and stroke. Post-mortem examination revealed different or unsuspected causes of death in 8 patients (12.7\%). Three out of the 8 patients died due to gastrointestinal disease. An unsuspected reason for heart failure was identified in 3 patients. Generalized lymphoma was not detected in one patient undergoing urgent surgery as well as pulmonary embolus in the latest patient. Additional findings not revealed during life were disclosed in another 6 patients, in whom the clinical and autopsy causes of death were in agreement (Table IV and V).

\section{DISCUSSION}

Traditionally, post-mortem analysis has served as the gold standard and final arbiter. Its major advantage, besides detailed macroscopic examination, is the possibility of tissue sampling for histological examination. This may be useful in determining myocardial infarction, ARDS, renal diseases, and other diseases detected mainly microscopically. Despite the apparent importance of autopsy, the number of studies in the literature has been very low in recent years. The autopsy rate in the literature varies from $24 \%$ to $88 \%$, and is much lower than our rate of $91.3 \%$ on average. ${ }^{(3-6,9)}$ We believe autopsy is an important source of knowledge and an integral part of medical education, namely in teaching hospitals. We fully agree with the statement of Cheng ${ }^{(10)}$ who emphasized that if one did not learn from the patient while he was alive, one should try to learn after the patient had died.

The extent to which autopsy results have agreed or disagreed with the clinical diagnosis varies in different clinical settings. A high agreement rate was documented in the cerebrovascular disorders, cardiac surgery and trauma group, while a somewhat lower rate was seen in thoracic surgery patients. ${ }^{(9)}$ Low agreement was demonstrated in the transplant group of patients. ${ }^{(7,8)}$ Our results do support these data, because the agreement rate of $87.3 \%$ is almost the same as the figure published by Goodwin. ${ }^{(5)}$ The most frequently overlooked diagnoses, according to the literature, were malignancies, infections, pulmonary embolism and gastrointestinal hemorrhage. ${ }^{(7,8)}$ These discrepancies depend on the quality of the diagnostic tools available, but diagnoses such as pulmonary embolism and gastrointestinal diseases continue to be a significant diagnostic challenge, even these days. In our experience, these complications often occur in severely ill patients with limited contact with the hospital staff. Their clinical picture is not distinct a usual, which might be one of the reasons for misidentifying the proper diagnosis. Therefore, preventive measures in such patients are of utmost importance. In consensus with this experience are data from the literature showing that the longer the length of stay in an ICU, the more frequent inaccuracy was discovered post mortem. ${ }^{(8)} \mathrm{We}$ cannot confirm these data, because the length of stay in our patients does not influence the diagnostic accuracy.

In our mortality analysis, we always aimed at identifying the cause of death. In patients where there was little to find at autopsy, the cause of death has been attributed to the underlying cardiac disease for which the patients were operated on. Due to this approach, the most common cause of death was cardiac death, a finding consistent with literary data. ${ }^{(3,5,6)}$ In contrast to these published series, the second most common cause of death was multiorgan failure. This entity occurred in patients who mostly died at a later postoperative date. The primary insult is often difficult to identify. Judging the clinical picture, we can speculate cardiac failure or central nervous injury were the culprits, followed by failure of other organs. Morphological changes on histological examinations of other organs may or may not be present, because failure can be functional at the beginning. Multiorgan failure seems to be the cause of death in an increasing number of patients due to steadily improving care about high-risk patients with several preoperative comorbidities and postoperative complications.

More clinical information given to the pathologist performing and interpreting the autopsy is useful. Therefore, the presence of a surgeon or another staff member is required at the time of autopsy, because clinical views can contribute to a more precise and accurate result of the post mortem study.

In conclusion, autopsy may identify an undiagnosed cause of death in a considerable proportion of patients following cardiac surgery. Moreover, some additional or overlooked findings can contribute to the final picture of the clinical failure. Even in the current era of very sophisticated examination methods and devices, post-mortem information remains to be a standard and an important tool for the improvement in clinical practice we all seek.

\section{REFERENCES}

1. Lee PN. Comparison of autopsy, clinical and death certificate diagnosis with particular reference to lung cancer. A revue of the published data. APMIS 1994;45 (Suppl): 11-42. 
2. Lee AHS, Gallagher PJ. Post-mortem examination after cardiac surgery. Histopathology 1998;33:399-405.

3. Zehr KJ, Liddicoat JR, Salazar JD, et al. The autopsy. Still important in cardiac surgery. Ann Thorac Surg 1997;64:380-3.

4. Deiwick M, Lohrer A, Hoffmeier A, Baba HA, Bocker W, Sheld HH. Postoperative death should be followed by autopsy - an analysis of the autopsy finding of the years 1990 and 1991 in heart sugery center. Thorac Cardiovasc Surg 1999;47:82-7.

5. Goodwin AT, Goddart M, Taylor GJ, Ritchie AJ. Clinical versus actual outcome in cardiac surgery: a post-mortem study. Eur J Cardio-Thorac Surg 2000;17:747-51.

6. Lee AHS, Borek BT, Gallagher PJ, et al. Prospective study of the value of necropsy examination in early death after cardiac surgery. Heart 1997;78:34-8.
7. Stevanovic G, Tukanovic G, Dotlic R, Kanjuh V. Correlation of clinical diagnoses with autopsy finding: a retrospective study of 2145 consecutive autopsies. Hum Pathol 1986;17:1225-30.

8. Mort TC, Yeston NS. The relations of pre mortem diagnoses and post mortem findings in a surgical intensive care unit. Crit Care Med 1999;27:299-303.

9. Ooi A, Goodwin AT, Goddard M, Ritchie AJ. Clinical outcome versus post-mortem finding in thoracic surgery: a 10-year experience. Eur J Cardio-Thorac Surg 2003; 23:878-82.

10. Cheng TO. The autopsy: Still important. To the editor. Ann Thorac Surg 1998;65:597-8.

Received 27 October 2005

Accepted 19 December 2005 